\title{
The Key Factor of Acid Mine Drainage (AMD) in the History of the Contribution of Mining Industry to the Prosperity of the United States and South Africa: A Review
}

\author{
Shinji Matsumoto, Hideki Shimada, Takashi Sasaoka \\ Department of Earth Resources Engineering, Kyushu University, Fukuoka, Japan \\ Email: shinji12@kyudai.jp
}

Received 26 May 2016; accepted 22 July 2016; published 25 July 2016

Copyright (C) 2016 by authors and Scientific Research Publishing Inc.

This work is licensed under the Creative Commons Attribution International License (CC BY). http://creativecommons.org/licenses/by/4.0/

\section{c) (i) Open Access}

\begin{abstract}
Mining industry has significantly contributed to the prosperity of the nation with economic growth, whereas mining operation has caused Acid Mine Drainage (AMD) with the abandonment of mines. As some researchers suggest, the history of AMD is, generally, affected by the change in not only mining industry but also in social and economic conditions. Thus, historical analysis is an effective way to find the key factors of AMD. In this study, in order to find the key factors of AMD, we examine the history of the United States (U.S.) and South Africa, where their economy had been developed owing to the large-scale mining, based on the findings in the previous studies. The results indicated that the abandoned mines due to the economic depression triggered AMD in the U.S. and South Africa. While the U.S. had progressively adopted anti-AMD methods in terms of prevention, prediction, and remediation (PPR) as a comprehensive approach, especially since the 1970s onwards because of the rise of environmental consciousness as well as strict regulations, South Africa is at the early stage of implementing the regulations following PPR. The public attention should be directed to environmental conservation in addition to the implementation of the regulations in South Africa. The improvement in socio-economic conditions is, additionally, necessary for the rise of environmental consciousness in South Africa in the light of the three pillars of sustainable development: social, economic, and environmental elements.
\end{abstract}

\section{Keywords}

Acid Mine Drainage (AMD), Mining Industry, South Africa, The United States, Historical Analysis, Socio-Economic Conditions 


\section{Introduction}

The development of resources, including every type of resources such as coal and metals, has a negative impact on the environment. Acid Mine Drainage (AMD) is one of serious environmental problems caused by mining activities such as surface mining or underground mining. This problem is attributable to the contact of sulfide minerals in waste rocks with water and oxygen during the operation in mining. Acidic water has a negative influence on the nature; thereby, it has to be prevented within an operation in mining [1]. The occurrence of AMD can be classified into two cases: it derives from abandoned and ownerless mines or the failure of treatment of mine drainage [2]-[6]. Most of the cases result from the exposure of sulfide minerals in waste dumps to air and rainfall after the abandonment of mines in the world. Thus, there is a close connection between resource development and AMD issue.

The United States (the U.S.) and South Africa are one of the resource-rich countries in the world. The mining industry has significantly contributed to the prosperity of the nation with economic development and social progress over the past century in the countries. However, AMD issue has occurred in compensation for the resource wealth. The occurrence of AMD has been reported with a rapid change in coal production over the past several decades in South Africa [4] [7]. South Africa is facing this issue derived from abandoned mines after the large-scale mine closure since 1970s, especially from underground mines in recent years [4] [8] [9]. This case was highlighted over the past 20 years, and this is one of the features of serious conditions of AMD in South Africa. Moreover, socio-economic challenges, such as the gap between the rich and the poor and a public health challenge, complicate the understanding of AMD [8]. In the U.S., AMD is also mainly attributed to the coal mines abandoned during the economic crisis in the 1900s [10]. Some of the abandoned mines still generate AMD and affect the natural aquatic systems in the region [11] [12]. While a great deal of research on AMD has been conducted in the U.S., they have proactively addressed AMD as a critical issue for the nature. Thus, both of the countries have confronted the challenges of AMD originated with mining in the past. Although it is true that the mining industry has played an important role in the development of a nation in the history of the U.S. and South Africa, the resource development resulted in AMD [13] [14]. Since the history, including the change in economic and social conditions and in the life style, has been significantly affected by mining industry, the history of AMD attributed to mining relates to socio-economic issues in the countries [15] [16].

The interrelation between environmental impacts and the development of industry was elucidated throughout the history of the nation in the past study [17]. They found out the main cause of social crisis and the relationship by reviewing the history over the past century. Additionally, the relationship between significant environmental impacts and potash extraction in the Bages region in Spain was revealed by historical analysis [18]. It was stated that a historical perspective which includes socio-economic points is useful to understand the basis of current socio-ecological challenges and socio-technical configurations. These results indicate that AMD issue needs to be discussed in terms of not only an environmental perspective, but also socio-economic point including a change in social and economic conditions and in mining industry.

In this study, in order to find the key factors of AMD, we examine the history of the U.S. and South Africa, such as the development of mining industry, the measures against AMD, and the change in social and economic conditions. Based on the factors related to AMD, we discuss the solution to AMD issue.

\section{Prosperity of a Nation with Development of Mining Industry}

\subsection{United States}

\subsubsection{Beginning of Mining Industry: The 18th and the 19th Centuries}

The U.S. is one of the resource-rich countries in the world, and the economy has developed with the exploitation of resources [13]. The development of coal and gold, especially in California and Appalachian region during the interwar period has significantly contributed to the growth of the industry and the prosperity of the U.S. [19] [20].

Some parts of the area in North American continent had been colonized by British until the American Declaration of Independence in 1776 [18]. The U.S. had heavily relied on foreign exchange obtained by the export of agricultural products until the early 1800s [21] [22]. Agricultural products were mainly exported in the early 1800s and the local people lived off the land. In ca. 1701, coal was found along the James River, near presentday Richmond, Virginia (VA). Coal had not been intensively mined for commercial use until the mid-1800s 
although a large amount of coal was found around West Virginia [23]. However, the Monroe Doctrine in 1823 might promote the rapid development of coal with the increase in the domestic demand for coal triggered by the growth of industry [24]. America began to move toward isolationism and adopted a non-interference policy with Europe after the event, leading to the beginning of the settlement of the American West. In the early 1800s, heavy industrial area and large cities appeared in the region around the Appalachian Mountains where a large amount of coal existed [25] [26]. The access to the region by trains was established during the Transportation Revolution from the mid-1800s to the late 1800s as shown in Figure 1, resulting in the promotion of the development of coal in the region. In 1869, transcontinental railway to the American West was constructed, and the development of the west region was accelerated [27] [28]. On the other hand, during the settlement of the America in the1840s, the findings of gold in the American river by John Sutter, who was a farmer, attracted many people from Europe to west region in the U.S., California [29]. This is called as the California Gold Rush, resulting in building large cities in the west region and a large-scale development of gold. At the same time, the construction of the Fairmont, Morgantown, and Pittsburge railroad enabled them to transport coal and to travel a long distance. This accelerated a rapid expansion of the development of coal in the West Virginia [30]. Thereby, the exploitation of coal and gold in the U.S. has begun with the increase in the demand for coal along with urban growth. The change of the annual U.S. index of industrial production in Figure 2(a) and Figure 2(b) indicates the rapid change in the industry in the U.S. originally resulted from the Monroe Doctrine in 1823. This index was shown in the past study for aggregating and expressing physical output across the 43 manufacturing and mining industries from 1790 to 1915 in the U.S. [31]. Significant increase of the change rate of the index is observed especially after 1823 in Figure 2(b). This suggests that the year in 1823 was a major turning point for the U.S. industry: rapid development of resources started since then.

These facts indicate that the change in socio-economic conditions is closely connected with resource development in the U.S. The rapid expansion of the resource production had been conducted for acquiring wealth regardless of environmental impacts.

\subsubsection{Occurrence of Acid Mine Drainage (AMD): The 20th and the 21st Centuries}

The World War I in 1914 forced European countries to expand the production of military products, and the U.S.

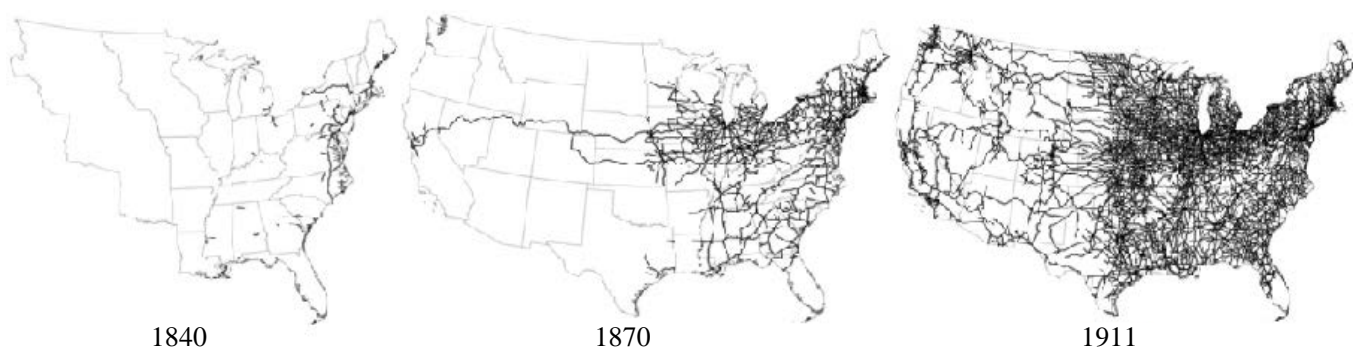

Figure 1. Changes in railway construction: construction of railway from 1840 to 1911 in the U.S. [26].

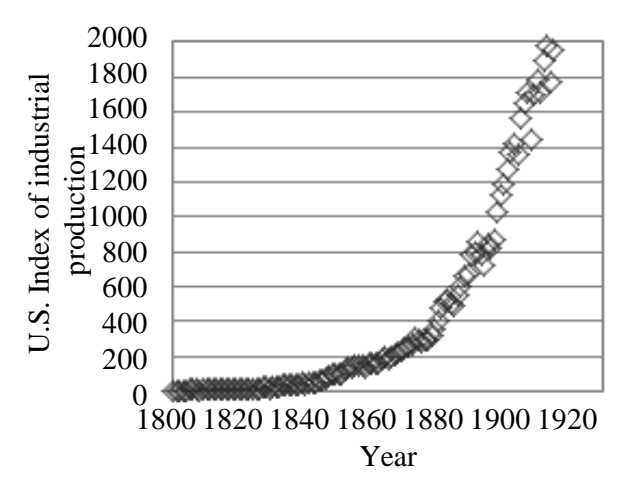

(a)

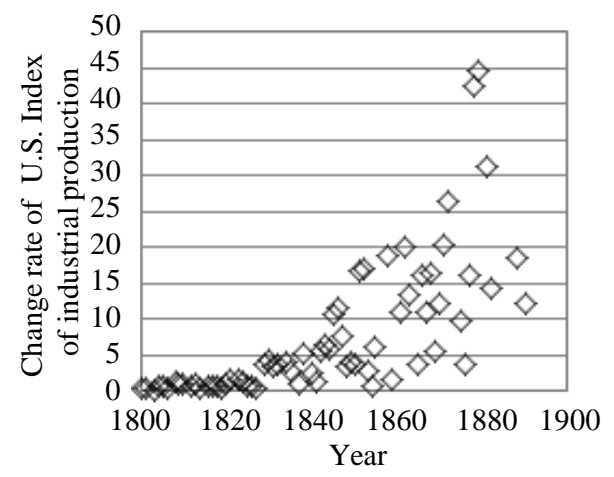

(b)

Figure 2. Change of the annual U.S. index of industrial production. (a): change of U.S. index of industrial production from 1790 to 1915, (b): change rate of the index: less than zero of the index is not shown [31]. 
expanded the export of steel and wheat [32]. The development of coal which was necessary for the production of industrial materials had especially increased during the World War I as shown in Figure 3 that shows the change in the production of Anthracite and Bituminous coal in Pennsylvania [33]. The region is one of the oldest coal mine areas in the U.S. and more than $70 \%$ of coal mining in the U.S. is concentrated in Kentucky, West Virginia, and Pennsylvania [34]. Both types of the production peaked in 1914, followed by the rapid increase in the production in 1945 during the World War II. Same trend was observed in other mines in the U.S. during the 1900s [35]. This indicates that coal production in the U.S. was dramatically expanded during the interwar period. The coal production on several seams such as the Pittsburgh seam and Maidsville in West Virginia was triggered by the World War I [36] [37]. Coal development, besides, had begun in many regions in North-East area in 1917, followed by a peak in coal production in Pennsylvania [33]. However, the economy in the mining area had gradually declined after the end of the World War I in 1920, resulting in mine closure in many small-scale mines [33] [36]. Many mining companies were forced to close the mines due to the drop in the price of coal and the recession through the Great Crash of 1929 while the U.S. was called as the factory of the world after the World War I [38]. Most of them became abandoned mines without a responsible person, and these inactions are the main cause of current AMD issues [11]. Thus, the mining industry in the U.S. has largely contributed to economic growth, followed by the fading of the importance of mining industry after the wars [33]. Many abandoned mines due to the decline of the mining industry during the interwar period finally resulted in AMD issues in recent years.

The U.S. economy had grown until the end of the World War II in 1945, whereas the mining industry faced a predicament [36]. The demobilization of soldiers had dramatically boosted the birth rate, which is called as a baby boom, after the World War II [39]. The technology, the society, and the industry in the U.S. had notably developed and changed with the increase of the population since the end of the war [40]. Moreover, the popularization of home electric appliances enabled the people to convey information, and it directed public attention to social and industrial issues in the U.S. [41]. AMD was often observed as serious water pollution from abandoned mines in many Appalachian states, such as West Virginia, Pennsylvania, and Ohio, due to extensive exploitation of coal since the World War II [4] [42]-[44]. Specific research on AMD began in the 1920s [42]; though; it had not received a lot of attention in the past. After the World War II in the 1940s, some of the institutions started to increasingly focus on AMD issues by identifying serious situation around the abandoned mines. The United States Bureau of Mines (USBM), which was established in 1910 as the largest of the Federal mining research centers operated by the Bureau of Mines under the U.S. department of the Interior, the U.S. geological survey, and the Appalachian Regional commission were collaborating on the investigation of the situation in the Appalachian from the1960s onwards [42] [45]. Many investigations and researches on the prevention and the prediction of AMD were conducted in the areas by the institutions. Based on the results, the prediction and the prevention methods were proposed in the 1960s [42] [46]. In addition to the establishment of measures against AMD in the mid-1900s, the negative impacts of AMD on the nature, such as high acidity in river and death of fishes, in Appalachian area and California area were frequently reported through the investigation [47] [48]. As a result of the extensive investigation and research, the Clean Water Act was enacted by the U.S. congress in

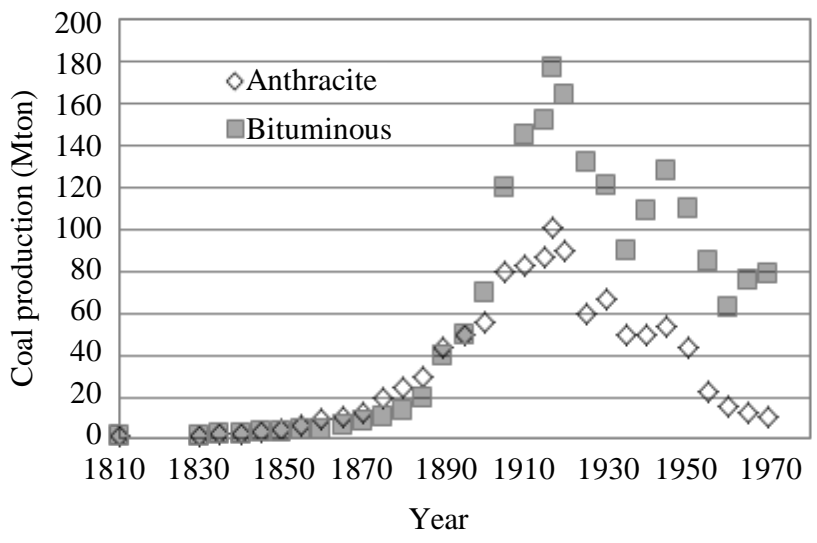

Figure 3. Annual Anthracite and Bituminous coal production in Pennsylvania from 1810 to 1970 [33]. 
order to promote the improvement of water quality in 1972 as summarized in Table 1 [49]. This act was originally enacted in 1948; however, the act in 1972 was a comprehensive approach to the water pollution. This required mines to treat the waste water from the mines before discharging. Additionally, Surface Mining Coal and Reclamation Act (SMCRA) was enacted in 1977 with the aim of requiring a tax on coal production to secure a fund for rehabilitation activities at abandoned mines as shown in Table 1 [49]. Thus, the U.S. established the measures and set the rules for preventing the occurrence of AMD from abandoned mines as a first step.

Another challenge in the U.S. was to establish the technology for the treatment of AMD with low-cost and less work and to predict AMD. Huntsman et al. found that amelioration of AMD naturally occurred through Sphagnum bogs in Ohio and West Virginia in 1978 [50]. This attracted the interest of researchers in utilizing the nature for remediation of acidic water with low cost, which is called as passive treatment system. In the same year, the guideline was developed by the Environmental Protection Agency (EPA), which is an U.S. administrative agency for environmental conservation, in order to evaluate and predict AMD by static and kinetic test in 1978 [51]. These methods have significantly contributed to the works of the regulatory agencies, the mining industry, and the research institutions. Thus, the framework for the prevention of AMD, the remediation of polluted water, and the predictive assessment of AMD has begun in the U.S. In 1986, the EPA, additionally, established the National Network for Environmental Management Studies (NNEMS) to attract the interest of higher education students in environmental careers [52]. This indicates that the U.S. government also tried to approach to AMD in the light of the cultivation of human resources. On the other hand, the investigations conducted by government agencies and research institutions revealed that $10 \%$ of stream in the Appalachians region was polluted by AMD [48]. The cost for the remediation of AMD in the Appalachian area by chemical treatment was, besides, estimated in 1987 [43]. According to the EPA report in 1995, ten thousand km of stream in Pennsylvania, Maryland, Ohio, and West Virginia was finally polluted by AMD [53].

To sum up, the changes in the U.S. history, such as the development of transportation, changes in economic conditions, the improvement in living standards after the World War II, and drawing the public's and government's attention to the water pollution caused by mining in the past, were identified as key factors in the history of AMD. Based on the results of the investigation and the laboratory experiments, the U.S. has, furthermore, approached to AMD issue from three viewpoints: points of prevention, remediation, and prediction assessment of AMD.

\subsection{South Africa}

\subsubsection{Beginning of Mining Industry: The 18th and the 19th Centuries}

South Africa has drawn attention as a resource-rich country in the world. They are the world's leading producer of not only coal but also metals such as gold and platinum [54]. The mining industry stems from the discovery of resources such as coal and gold in the South Africa in 1800s, and it has created a great wealth for a brief period [55]. South Africa achieved significant economic growth by developing the resources and their economy

Table 1. Measures for the treatment of AMD in the U.S. [49].

\begin{tabular}{cc}
\hline Year & Act \\
\hline 1948 & Federal Water Pollution Control Act \\
1956 & Water Pollution Control Act of 1956 \\
1961 & Federal Water Pollution Control Act Amendments \\
1965 & Water Quality Act of 1965 \\
1966 & Clean Water Restoration Act \\
1970 & Water Quality Improvement Act of 1970 \\
1972 & Federal Water Pollution Control Act Amendments \\
1977 & Clean Water Act of 1977 \\
1981 & Municipal Wastewater Treatment Construction Grants Amendments \\
1987 & Water Quality Act of 1987 \\
2014 & Water Resources Reform and Development Act of 2014 \\
\hline
\end{tabular}


has been heavily dependent on mining industry, whereas the rapid development of resources has caused a negative effect on the environment. Acid Mine Drainage is one of the serious issues caused by mining activities and often reported in the last few decades in South Africa [11] [12].

Jan van Riebeeck from the Dutch East India Company visited the South Africa continent and set the region as Cape of Good Hope in 1652, leading to the Netherlands Cape Colony [56]. This land had developed with the territorial dispute between the United Kingdom and the Netherlands. The development of the South Africa derived from the prosperity of the Cape Town. The land grab had occurred between native people of the region and the states which colonized the area until in the second half of 1800 . When the slavery was abolished within the Cape Colony in 1834, South Africa was divided into four main regions: Cape colony, Natal colony, Transvaal republic (South African Republic), and Orange Free states [57]. After a large-scale deposit of diamond was discovered in Kimberley within the borders of the Orange Free State and the British Cape Colony in 1867, many people moved to the area by train from the Cape Colony to the area [58]. In 1892, the Cape railway from the Port Elizabeth and the East London to Kimberley was, additionally, completed as shown in Figure 4 [59] [60]. This event triggered a rapid development of the regions around the Kimberley with the construction of infrastructure and population growth. The Kimberley town became the second largest town in 1873, while the discovery of diamond resulted in the long-running territorial dispute over resources [58].

Many gold diggers moved to the Witwatersrand located to the south of the Transvaal for benefits after the new deposit of gold was discovered in the area in 1886 [58]. In 1887, the Nederlandsche Zuid-AfrikaanscheSpoorweg Maatschappij (NZASM), the railway company established in the Transvaal in 1884, accepted the proposition in which the Pretoria was to be connected to the Delagoa Bay by railway, and it was completed in 1894 [61] [62]. Many people moved to the region by the Cape Government railway and the Witwatersrand underwent a rapid development of the town by 1898: this is generally considered Gold Rush in South Africa [63]. The region had flourished same as the Kimberley, resulting in large cities around the Witwatersrand such as the Johannesburg and the Centurion. Besides, a large quantity of coal was discovered in the region in the 1880s. While sixteen miles of railroad was completed between the Johannesburg metropolis and the Boksburg coal mines in 1890, coal mining began in the Witbank and the Middelburg area in 1894 [9]. A large amount of coal had been excavated in the large area from the Witbank and the Middleburg to the Mpumalanga in the late-1800s [64]. Thus, the development of resources had actively been conducted in the late-1800s in South Africa. The development and the construction of transportation rapidly progressed simultaneously in order to make a profit from resources. The rapid exploitation of resources without consideration for the impact on environment in the late-1800s may lead to AMD in recent years in South Africa.

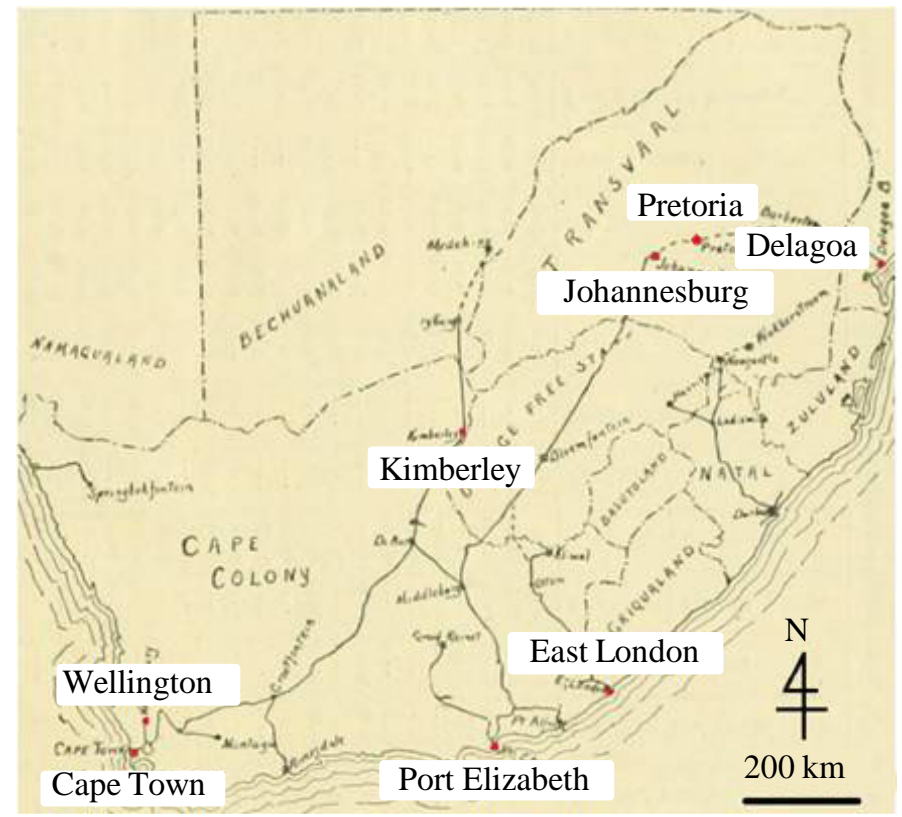

Figure 4. Railroads in South Africa in the late 1800s [60]. 


\subsubsection{Occurrence of Acid Mine Drainage (AMD): The 20th and the 21st Centuries}

In 1910, Cape Province, Natal Province, Transvaal Province, and Orange Province were finally merged into the Union of South Africa [65]. After the unification, South Africa had tried to achieve the political stability until the achievement of complete elimination of apartheid-related law in 1991. The infrastructure was gradually improved over this period, while South Africa was economically and socially unstable. On the other hand, a large profit from the development of resources has significantly contributed to the growth of the nation after the founding of the country. There were 112 of mines including diamond and coal mines in 1986 according to Frank [66]. However, environmental impacts have begun to be reported in the late-1900s in the South Africa. The environmental harm caused by mining industry were recognized as serious issues in the world at that time, resulting in furtherance of investigation and the establishment of regulations [67]. This suggests that the efforts toward waste water problems from abandoned and existing mines have commenced in South Africa since then. Moreover, 112 of mines in 1986 had decreased until 53 in 2000, indicating that the waste water problems might start to occur from the abandoned and closed mines [66]. The investigation focusing on the water quality in drainage from closed mines has started since 1990s, whereas AMD began to occur in the Western Basin where there were many abandoned gold mines in 2002 [68]. The AMD issues in the area are one of the serious waste water issues and have continued to this day. Additionally, Thabo Mvuyelwa Mbeki, who assumed the presidency in 1999, began to take measures against economic and social issues such as economic differentiation between races, security problem, and HIV in South Africa [69]-[71]. In spite of an intense effort, the issues such as income difference, high unemployment rate, and security problems had not completely resolved. Thus, South Africa suffered from the issues in addition to AMD in the late-1900s.

In regard to AMD issues, several kinds of measures were implemented to improve the situation since the late-1900s, such as Water Service Act (WSA) in 1997, National Water Act (NWA) in 1998, and the National Environmental Management Act (NEMA) 107 in 1998 [72]. The purpose of them was to promote the prevention and the remediation of polluted water through the regulations. In order to reduce the environmental impacts, South Africa, moreover, established the Wonderfontein Regulations Steering Committee (WRSC) and the National Framework for Sustainable Development (NFSD) in 2007 [72]. However, the electricity shortage became an important issue domestically in 2007, and the pumping system ceased in the Central Basin in 2008, resulting in the occurrence of AMD [68]. The South Africa performed the National Environmental Management: Waste Act (NEMA: WA), the Integrated Coastal Management Act 24, and the Waste Act 59 in 2008, aiming at further regulation of the progress of environmental issues by mining industry, while the domestic economy faced a predicament due to high unemployment rate [73] [74]. This had accelerated the closure of mines; meanwhile, severe restriction on mine closure plan had been implemented. The pumping system finally ceased in the Eastern Basin and the mine void begun to be decanted in 2011, resulting in AMD in the region [68].

In short, South Africa has confronted AMD issues as well as social and economic issues. These problems which continue today have a short history since it started to occur. There are, additionally, many abandoned mines which may contribute to AMD in recent years in South Africa [75], and the investigation to assess the situation and several practices are still ongoing.

\section{Historical Analysis to Approach to AMD Issue}

\subsection{Historical Turning Points in the History of AMD in the U.S. and South Africa}

One of the turning points in the U.S. history of the development of resources is the Monroe Doctrine announced by James Monroe, the 5th U.S. president in 1823 [24]. This is a diplomatic policy promoting the isolationism of the U.S., resulting in the development of domestic industry and economic independence [25]-[28]. Coal mining began in Appalachian region with the industrial development, leading to the appearance of large cities in the region. The transportation system also began to be developed with the concentration of population and products in the large cities. The railway was intensively built in the U.S. for the sake of transporting labors and products from the early 1800s and to the mid-1800s when many people began to explore the West [25] [26]. The active movement of people and products through the construction of railway in the early 1800s was another transition stage in the history of the U.S., and it promoted the development of resources. On the other hand, the construction of the Cape railway which promoted the transfer of people and goods was the turning point in South Africa. The development of resources significantly progressed due to this event after the discovery of gold and diamond in the Kimberley and the Witwatersrand. The transportation similarly promoted the movement of people and 
goods in South Africa in the late 1800s [58] [60]-[63]. Thus, the development of resources led to the appearance of large cities and the population concentration through the population growth in the region as in the case of the Appalachian region in the U.S. and the Kimberley in South Africa. The construction of railway was promoted based on the national policy in both countries, leading to further promotion of the development of resources. The development and the construction of railway mutually promoted, and it contributed to the regional development in the countries. Basically, the construction of infrastructure and the development of resources which caused regional development were one of the key factors to approach to AMD as shown in Figure 5. Ferreira and Lloyd also argued that economic development brought by the development of resources in the countries and industrialization is regarded as the priorities for regional development [76].

The interwar period between the World War I and II was another turning point in the history of the U.S. The production of coal in the Appalachian region dramatically increased in the prewar and postwar era in the aim of utilizing them for manufacture, trade, and fuels [35]. Most of the coal was mined for the profits and the utilization during the period as described in Figure 3. It seemed that the public attention was directed to national or regional development and the acquisition of wealth during the war. However, the economic depression in 1929 forced some of the coal mines in the U.S. to close, and some of them were abandoned [33] [36]. These abandoned mines caused AMD issues in the U.S. In South Africa, much of resources might be mined without the regulations of mining in the past when the production of resources peaked. Especially in around 1900, when railway was rapidly constructed in South Africa before founding of the nation, the resources were mined for the purpose of wealth. Though, South Africa had confronted an unstable economic and social situation even after the establishment of South Africa due to political insecurity. The change in the price of resources such as gold, diamond, and coal led to the closure of some of the mines and the abandonment, while many people struggled for wealth in mining industry. The number of the mines halved owing to the closure of the mines during the late 1900s in South Africa, resulting in the occurrence of AMD [66]. These facts suggest that a sudden change in economic conditions is one of the key factors to explain the change in mining industry in the U.S. and South Africa and the cause of the abandoned mines. To sum up, the rapid development of resources and transportation for the profit contributed to the regional development, followed by the abandonment of mines after the changes in economic conditions in the U.S. and South Africa. These key factors are important to explain the occurrence of AMD caused by the abandonment of mines in the countries.

\subsection{Key Factors to Approach to AMD in the U.S. and South Africa}

The U.S. has begun to take measures against AMD earlier than in South Africa. Although the United States Bureau of Mines (USBM), established in 1910, started promoting safety activities in mining industry, the substantial efforts to tackle AMD issues has begun since the end of the World War II in 1945 [45]. The public attention to wealth began to be directed to industrial and social problems with the improvement of living standard since the late 1940s [39]-[41]. The occurrence of AMD from abandoned mines has been reported since the 1950s across the U.S., and the experiments on waste water from coal mines were performed for the first time [77]. AMD issues were intensively studied through the investigations and the experiments in a variety of ways from the 1950s to the 1960s after the change in attention. Dead fishes were observed in the river in the U.S. through

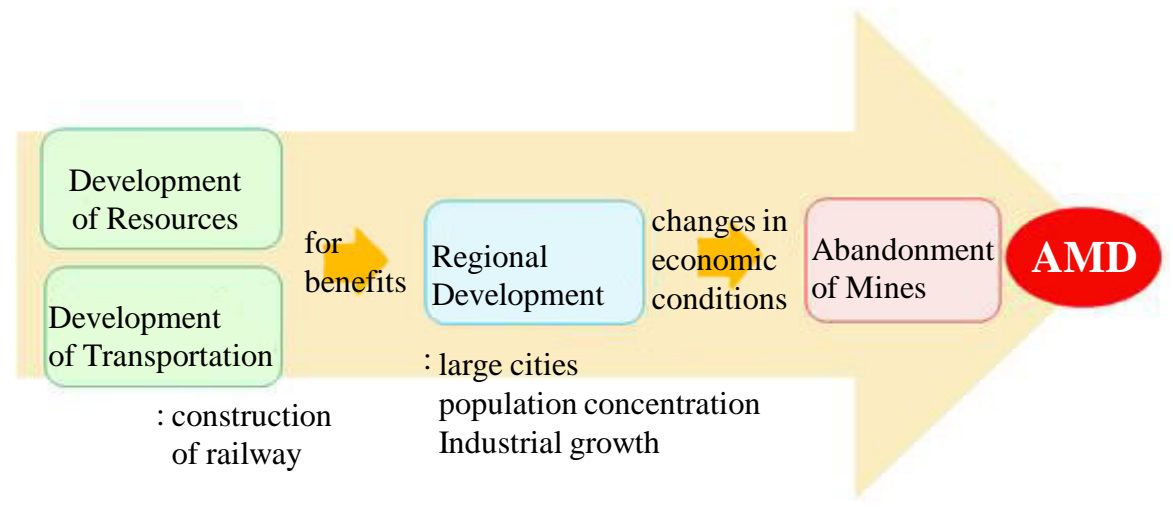

Figure 5. Key factors to explain the occurrence of AMD in the U.S. and South Africa. 
the investigations in the 1960s [42]. Additionally, a wide variety of ways to prevent and to evaluate AMD was proposed with the guidelines of the investigation and the temporary measure against AMD [46]. The mining industry had been unregulated until 1965 in the U.S.; however, according to previous study, the SMCRA in 1977 and Clean Water Act in 1972 began to regulate the mining industry [43]. These regulations prevented the mines from discharging waste water into the river without permissions and forced them to secure a sufficient budget for remediation of waste water by imposing a tax on the operation in mines. The intensive investigation and research from the 1950s to the 1960s were responsible for the success of enacting the comprehensive and the specific regulations. The measures against AMD were also taken from many different perspectives with the enactment of the regulations in the U.S. The National Environmental Policy Act (NEPA) in 1969, for instance, forced the U.S. government to establish the framework for environmental conservation [78]. In 1977, the SMCRA provided the standards for environmental protection in mines and the Partnership for Acid Drainage Remediation (PADRE) in Europe, a permanent commission of the International Mine Water Association (IMWA), distributed the guidelines to the mining industry on analysis methods for classification of overburden in 1979 while the EPA proposed the assessment method of AMD [44] [51] [77]. This indicates that assessment strategy and preventive measures were provided in the U.S. in the mid-1900s. However, the investigations conducted by PADEP in 1984 revealed that the mines which had been closed before enacting the Federal Water Pollution Control Act Amendments in 1972 and the Clean Water Act in 1977 caused serious pollution of the river [43] [44]. The Bureau of Abandoned mine reclamation program in Pennsylvania which was performed through PADEP announced that the U.S. Bureau of Mines would accept the responsibility for remediation of the pollution from the ownerless mines. More than 800 of requests for the practice were accepted by the U.S. Bureau of Mines then, indicating that the practices for remediation of AMD began in the U.S. at this time [43]. Other efforts in regard to AMD such as the research on remediation of AMD by wetland treatment, the establishment of Acid Base Accounting (ABA) method to assess AMD by the EPA, and program to direct student's attention to environmental issues have started since 1970s [43] [51] [52]. These practices were concurrently conducted up to the present date.

Specific features of measures against AMD can be found in the history of the U.S. as shown in Figure 6. The detailed survey and the research on AMD, firstly, started with the implementation of temporary measures after drawing the public attention from wealth to environmental issues. The regulations to prevent AMD were enacted based on the results of the investigations and the studies. The methods to assess and to predict AMD were, additionally, proposed along with the start of ongoing work for remediation of AMD. There are, basically, several stages of measures against AMD in the U.S. as shown in Figure 6. Furthermore, the measures against AMD in the U.S. can be categorized into several categories as follows: prevention, prediction, and remediation (PPR) as shown in Figure 7. The Clean Water Act in 1972 and the SMCRA in 1977, which set the rules to regulate the outflow of waste water from mines, played a role in preventing AMD [43]. The guidelines to mining industry by the PADER in 1970 and the standard of assessing AMD by the EPA are classified into the category of prediction [51] [77]. The announcement that the U.S. Bureau of Mines would have a responsibility for remediation of AMD from abandoned mines in Pennsylvania in the 1980s in Bureau of Abandoned mine reclamation program was the measures against AMD in terms of remediation [43]. Thus, the U.S. has approached to AMD issues in the light of the three key factors of prevention, prediction, and remediation (PPR). It is also can be seen that the measures can be effective only when they are enacted in combination with each factor. For example, even if the outflow of acidic water from mines is regulated and prevented, there is a confusion of responsibilities for AMD from ownerless mines. The ownerless mines abandoned before enacting the regulations are exempted from the application of the rules. In order to take measures against the waste water from the mines, the remediation of the

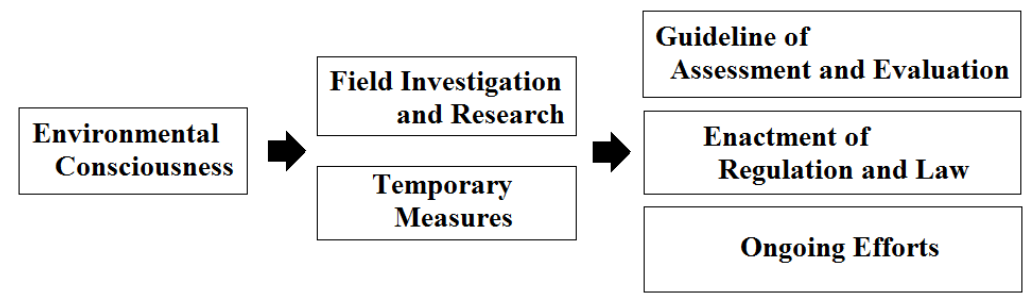

Figure 6. Several stages of measures against AMD in the U.S. 


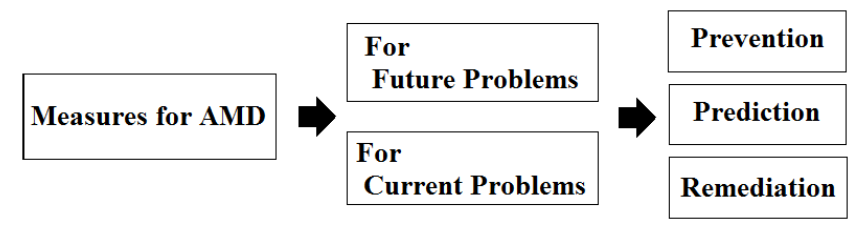

Figure 7. Key factors to approach to AMD in the U.S: important factors of prevention, prediction, and remediation (PPR).

polluted water is necessary in the case. In addition to the efforts in terms of prevention and remediation, the framework to assess the situation in order to predict future problems is, besides, required for measures against AMD. Hence, it is important to approach to AMD in terms of the three important factors of PPR in Figure 7 in accordance with the stages in measures against AMD in Figure 6.

In South Africa, environmental problems have begun to be reported since the late 1900s, leading to the beginning of the investigations [4] [68]. This clarified the main area where AMD occurred from abandoned mines in South Africa as shown in Figure 8: Western Basin, Central Basin, Eastern Basin, Free State Gold field, KOSH Gold field, Far Western Bain, Evander Gold Field, South Rand Gold Field, Mpumalanga Coal Fields, KwaZulu-Natal Coal Fields, and O'Kiep Copper District [68]. This situation in abandoned mines attributes to the closure of many mines in the late 1900s since the number of mines decreased from 112 in 1986 to 53 in 2000 [66]. Additionally, AMD began to occur in Central Basin in 2008 and in Eastern Basin in 2011 when groundwater started to fill the mine voids due to the stop of the pumping system caused by shortage of electricity [68]. Even though the WRSC and NFSD were founded in 2007 in addition to the WSA in 1997and the NEMA in 1998 with the aim of taking measures against AMD, it accelerated the closure of mines due to the strict rules [72] [73]. In Witwatersrand the council for geoscience (CGS) on behalf of the Department of Mineral Resources (DMR) has begun to work on the issues by summarizing the information on AMD [68]; however, AMD remained a huge problem in South Africa [8]. In order to improve the situation, South Africa started to work on further prevention of the occurrence of AMD through the regulation of the operation in mines by the Mineland Petroleum Resources Development Act (MPRDA) in 2004 and of a waste management by the NEMA:WA in 2008 [4]. Moreover, there are an international best practice guideline as the Global Acid Rock Drainage (GARD) Guide in which South African organizations have joined and the Department of Water Affairs (DWA) Best Practice Guidelines for Water Resource Protection in the South Africa Mining Industry and Impact Prediction [68].

When we compare the approaches to AMD between the U.S. and South Africa, some of the major measures against AMD are summarized in Table 2 and Table 3 in terms of the key factors of PPR. The table indicates that South Africa has tackled AMD issues from a view point of the key factors of PPR same as in the U.S. as shown in Figure 7. The NWA in 1998 is categorized into prevention and remediation. The MPRDA can be categorized into prediction in addition to prevention and remediation since it promoted the environmental management plan (EMP) [4]. In regard to the stages of measures against AMD as shown in Figure 6, there was not the turning point in which the public attention was directed to environmental issue from wealth in South Africa, as in the case of the United States according to previous research. The cooperative structure is, actually, considered one of the key points to tackle AMD in South Africa. Many people and organizations such as mining company, stockholders, residents, governments, and research institutions relate to AMD issue [79]. This suggests that a collaborative approach to AMD from many different perspectives is important to work on AMD. Additionally, Van Eeden et al. pointed out that a team of experts work on the determination of the priority hot spot of AMD in South Africa without public participation or community engagement [72]. They also mentioned that the consultation process proceeded in the absence of the majority of affected communities. Additionally, Shields et al. argued that the government has a responsibility to develop guideline for measures against AMD, and the industry must be recognized as the members who cope with AMD [79]. They also said that the public is responsible for being informed about natural resource management issues [79]. Thus, it is important to address AMD issue by all of the people and organizations related to AMD for sustainable development of mineral resources [72] [79]. In the U.S., a change in attention to environmental issues from wealth resulted in active research and investigations of AMD after the World War II as shown in Figure 6. The results, furthermore, led to the enactment of laws and regulations on AMD in the U.S. These facts indicate that not only the government but also public and several organizations played an important role in solving AMD, and this strategy is required in South Africa to resolve AMD issues. 


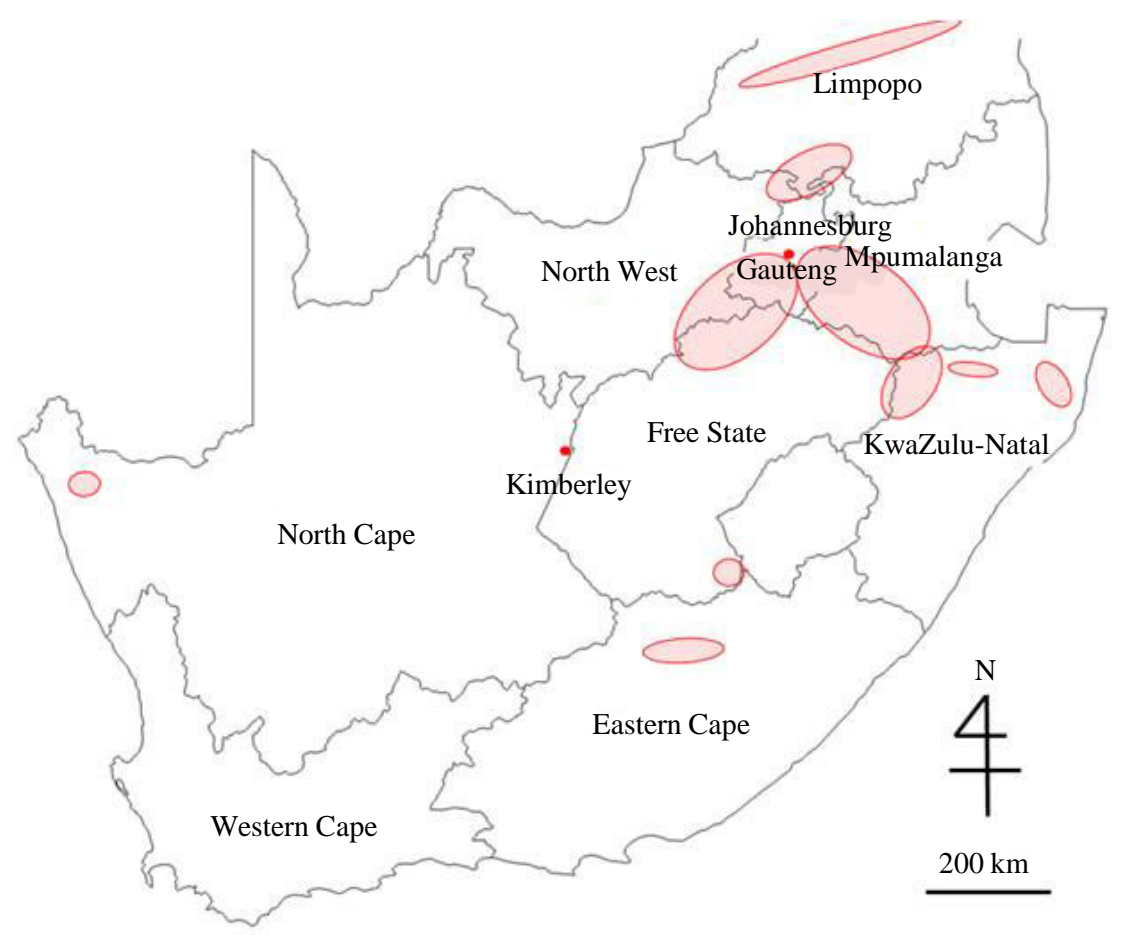

Figure 8. Main regions where AMD occurred in South Africa: the area with red color indicates the region where AMD occurred from abandoned mines [68].

Table 2. Summary of measures against AMD in the U.S. in terms of the key factors of PPR.

\begin{tabular}{|c|c|c|c|c|}
\hline Year & Measures & Prevention & Prediction & Remediation \\
\hline 1972 & Clean Water Act & $\mathrm{O}$ & & \\
\hline 1977 & Surface Mining Control and Reclamation Act (SMCRA) & $\mathrm{O}$ & & \\
\hline 1977 & National Abandoned Mine Land Reclamation Program & $\mathrm{O}$ & & $\mathrm{O}$ \\
\hline 1978 & EPA standard & & $\mathrm{O}$ & \\
\hline 1980s & Bureau of Abandoned Mine Reclamation & & & $\mathrm{O}$ \\
\hline
\end{tabular}

Table 3. Summary of measures against AMD in South Africa in terms of the key factors of PPR.

\begin{tabular}{lcccc}
\hline Year & Measures & Prevention & Prediction & Remediation \\
\hline 1997 & Water Service Act & O & & \\
1998 & Constitution and National Water Act (NWA) & O & O \\
1998 & National Environmental Management Act (NEMA) 107 & O & O & O \\
2004 & Mineland Petroleum Resources Development Act (MPRDA) & O & O & O \\
2006 & Mine and Environmental Management (MEM) guidelines & O & O & O \\
2008 & National Environmental Management: Waste Act (NEMA: WA) & O & O & O \\
2008 & Regional mine closure strategies & O & O & \\
\hline
\end{tabular}

The improvement of economic and social conditions is another key factor to approach to AMD in South Africa. The community becomes absolutely dependent on the economic opportunities generated by mining without any concern for environmental impacts, resulting in AMD in many cases [80]. It is difficult to direct the public attention to environmental conservation unless economic conditions are improved. Moreover, AMD in the Central Basin in 2008 and the Eastern Basin in 2011 began due to the cessation of pumping caused by the shortage of electricity [68], indicating that the social conditions in South Africa have to be taken into account as 
one of the key factors to resolve AMD issues.

For these reasons, AMD should be tackled from several perspectives. There is a need of a bird's eye view to assess the environmental risk [68]. AMD has to be tackled from not only environmental perspective but also the point of economic and social conditions which are the tree pillars of sustainable development proposed in 2009 [81]. South Africa is currently promoting environmental management policy which ensures the Growth Employment and Redistribution Strategy (GEA) [76]. Additionally, Accelerated Shared Growth Initiative for South Africa (ASGISA) was enacted in 2006 as a framework guiding all policy development in South Africa until 2014 [82]. This aimed to decrease the unemployment (below 15\%) and poverty (less than one-sixth of households) by 2014 as an effort on economic and social issues since 1990s, suggesting the beginning of measures against AMD from a point of economic and social perspective in South Africa. In regard to the situation, South Africa is currently at the planning phase after environmental survey over past few years as well as conducting ongoing efforts.

\section{Conclusions}

In this study, taking comparative historical method, we examined the history of the U.S. and South Africa, such as the development of mining industry, measures against AMD, and social and economic conditions in order to find the key factors of AMD. The findings can be summarized as follows:

1) There are several key factors to explain the occurrence of AMD in the history of the U.S. and South Africa. The regional development caused by the rapid development of resources and transportation for the profit and the changes in economic conditions are the important factor to explain the history of AMD in the countries.

2) There are several stages of measures against AMD in the U.S. The detailed survey and research on AMD started with the implementation of temporary measures after the change in attention from wealth to environmental issues. The regulations to prevent the occurrence of AMD were enacted based on the results of the investigations and the studies along with the establishment of the method to assess and to predict AMD and ongoing works for remediation of AMD.

3) The measures against AMD in the U.S. can be categorized into several types: prevention, prediction, and remediation (PPR). They were defined as the important key factors to approach to AMD. The measures can be effective only when they are enacted in combination with each other.

4) Whereas the approach to AMD in South Africa follows the key factors of PPR same as in the U.S., there was not the turning point that the public attention was directed to environmental issue from wealth in South Africa, as in the case of the U.S. South Africa is currently at the planning phase after environmental survey over past few years as well as conducting ongoing efforts.

5) In order to resolve AMD issues, the change in attention to environmental issue is required in South Africa as well as the improvement of social and economic conditions in terms of the tree pillars of sustainable development: social, economic, and environmental elements.

\section{Acknowledgements}

The authors are grateful to the Advanced Graduate Program in Global Strategy for Green Asia in Kyushu University for the financial support.

\section{References}

[1] Jennings, S.R., Neuman, D.R. and Blicker, P.S. (2008) Acid Mine Drainage and Effects on Fish Health and Ecology: A Review. Reclamation Research Group Publication, Bozeman, MT, 1-26. http://www.pebblescience.org/pdfs/Final_Lit_Review_AMD.pdf

[2] Harris, D.L., Lottermoser, B.G. and Duchesne, J. (2003) Ephemeral Acid Mine Drainage at the Montalbion Silver Mine. North Queensland. Australian Journal of Earth Sciences, 50, 797-809. https://www.hsph.harvard.edu/mining/files/ephemeral_acid_mine_drainage_at_the_montalbion_silver_mine.pdf http://dx.doi.org/10.1111/j.1440-0952.2003.01029.x

[3] Leigh, K. (2014) Evaluation Report: Kangaluwi Open-Pit Copper Mine in the Lower Zambezi National Park. Lower Zambezi Tourism Association. http://voices.nationalgeographic.com/files/2014/11/Evaluation-Report_-Mining-Lower-Zambezi_LZNP_Nov2014.pdf

[4] Makgae, M. (2012) The Status and Implications of the AMD Legacy Facing South Africa. Proceedings of the International Mine Water Association Symposium, Bunbury, 29 September-4 October 2012, 327-334. 
[5] Bussiere, B. (2009) Acid Mine Drainage from Abandoned Mine Sites: Problematic Acid Reclamation Approaches. Proceedings of International Symposium on Geo-environmental Engineering, Hangzhou, 8-10 September 2009, 111-125.

[6] Weber, P., Weisener, C., DiLoreto, Z. and Pizey, M. (2015) Passive Treatment of ARD Using Mussel Shells-Part I: System Development and Geochemical Processes. Proceedings of the 10th International Conference on Acid Rock Drainage and IMWA annual Conference, Santiago, 21-24 April 2015, 1167-1175.

[7] Eberhard, A. (2011) The Future of South African Coal: Market, Investment, and Policy Challenges. Working Paper 100, Program on Energy and Sustainable Development, Stanford University, Stanford.

[8] Feris, A.L. and Kotze, J.L. (2014) The Regulation of Acid Mine Drainage in South Africa: Law and Governance Perspectives. Potchefstroom Electronic Law Journal/Potchefstroomse Elektroniese Regsblad, 17, No. 5. http://ssrn.com/abstract=2556185

[9] Terence, S.M. (2011) The Impact of Acid Mine Drainage in South Africa. South African Journal of Science, 107, 1-7. http://www.sajs.co.za/sites/default/files/publications/pdf/712-5387-3-PB.pdf

[10] Smucker, N.J. and Vis, M.L. (2011) Acid Mine Drainage Affects the Development and Function of Epilithic Biofilms in Streams. Journal of the North American Benthological Society, 30, 728-738.

[11] Metesh, J.J., Jarrell, T. and Oravetz, S. (1998) Treating Acid Mine Drainage from Abandoned Mines in Remote Areas, Tech. Rep. 9871-2821-MTDC, Missoula, MT: U.S. Department of Agriculture, Forest Service, Missoula Technology Development Center, 1-18. http://www.rosemonteis.us/files/references/metesh-jarrell-oravetz-1998.pdf

[12] Simmons, A.J., Lawrence, R.E. and Jones, G.T. (2005) Treated and Untreated Acid Mine Drainage Effects on Stream Periphyton Biomass, Leaf Decomposition, and Macroinvertebrate Diversity. Journal of Freshwater Ecology, 20, 413424. http://dx.doi.org/10.1080/02705060.2005.9664756

[13] Macdonald, A. (2002) Industry in Transition: A Profile of the North American Mining Sector. International Institute for Sustainable Development, Manitoba, 1-146. http://www.iisd.org/pdf/2001/mmsd_na_mining_profile.pdf

[14] Murombo, T. (2013) Regulating Mining in South Africa and Zimbabwe: Communities, the Environment and Perpetual Exploitation. Law, Environment and Development Journal, 9, 31-49.

[15] Douglas, S. and Walker, W.A. (2015) Coal Mining and the Resource Curse in the Eastern United States. http://be.wvu.edu/phd_economics/pdf/14-01.pdf

[16] Terminski, B. (2012) Mining-Induced Displacement and Resettlement: Social Problem and Human Rights Issue (A Global Perspective). http://nbn-resolving.de/urn:nbn:de:0168-ssoar-327774 http://dx.doi.org/10.2139/ssrn.2028490

[17] Aidar, M.K. (2014) Ecological Problems of Middle Volga in the Second Half of the XXth Century: Historical and Ecological Analysis of Leading Industrial Regions Development. Life Science Journal, 11, 573-579.

[18] Mays, M.T. (2009) Historical Dictionary of the American Revolution. 2nd Edition, Scarecrow Press, Maryland.

[19] Christina, D.R. (1992) What Ended the Great Depression? The Journal of Economic History, 52, 757-784. http://dx.doi.org/10.1017/S002205070001189X

[20] Harvey, E.C. (1986) Coal in Appalachia: An Economic Analysis. University of Kentucky Press, Lexington.

[21] Acheson, T.W. (1993) New Brunswick Agriculture at the End of the Colonial Era: A Reassessment. Acadiensis, 22, 526. https://journals.lib.unb.ca/index.php/Acadiensis/article/viewFile/11944/12788

[22] Galenson, D.W. (1984) The Rise and Fall of Indentured Servitude in the Americas: An Economic Analysis. The Journal of Economic History, 44, 1-26.

http://www.colorado.edu/ibs/es/alston/econ8534/SectionIII/Galenson,_The_Rise_and_Fall_of_Indentured_Servitude_i n_the_Americas.pdf http://dx.doi.org/10.1017/S002205070003134X

[23] Eavenson, N.H. (1939) The Early History of the Pittsburgh Coal Bed. The Western Pennsylvania Historical Magazine, 22, 165-176. https://journals.psu.edu/wph/article/viewFile/2128/1961

[24] Laing, T.J. (1966) The Early Development of the Coal Industry in the Western Counties of Virginia, 1800-1865. West Virginia Archives and History, 27, 144-155. http://www.wvculture.org/history/journal_wvh/wvh27-2.html

[25] Van Atta, R.J. (2014) Securing the West: Politics, Public Lands, and the Fate of the Old Republic, 1785-1850. Johns Hopkins University Press, Baltimore.

[26] Atack, J. (2013) On the Use of Geographic Information Systems in Economic History: The American Transportation Revolution Revisited. The Journal of Economic History, 73, 313-338. http://dx.doi.org/10.1017/S0022050713000284

[27] Vetter, J. (2008) Field Science in the Railroad Era: The Tools of Knowledge Empire in the American West, 1869-1916. História, Ciências, Saúde-Manguinhos, 15, 597-613. http://www.scielo.br/pdf/hcsm/v15n3/03.pdf http://dx.doi.org/10.1590/S0104-59702008000300003 
[28] Kreiser, A.L. and Browne, B.R. (2011) Voices of Civil War America: Contemporary Accounts of Daily Life. Greenwood Press, California.

[29] Kenneth, N.O. (2004) Gold Rush Saints: California Mormons and the Great Rush for Riches. Arthur H. Clark Company, Glendale.

[30] Lewis, L.R. (1998) Transforming the Appalachian Countryside: Railroads, Deforestation, and Social Change in West Virginia, 1880-1920. The University of North Carolina Press, Chapel Hill.

[31] Davis, J.H. (2004) An Annual Index of U.S. Industrial Production, 1790-1915. The Quarterly Journal of Economics, 119, 1177-1215. http://www.jstor.org/stable/25098716 http://dx.doi.org/10.1162/0033553042476143

[32] Eloranta, J. (2015) “Weak” European States in the International Arms Trade, 1920-1937: The Impact of External Threats, Market Forces, and Domestic Constraints. Scandinavian Economic History Review, 50, 44-67. http://www.appstate.edu/ elorantaj/weakstates4.pdf http://dx.doi.org/10.1080/03585522.2002.10410801

[33] Latzko, A.D. (2011) Coal Mining and Regional Economic Development in Pennsylvania, 1810-1980. http://www2.yk.psu.edu/ dxl31/research/articles/coal.pdf

[34] Esterhuizen, G.S. and Gürtunca, R.G. (2006) Coal Mine Safety Achievements in the USA and the Contribution of NIOSH Research. Journal of the Southern African Institute of Mining and Metallurgy, 106, 813-820. http://www.cdc.gov/niosh/mining/UserFiles/works/pdfs/cmsai.pdf

[35] Flores, M.R. (2014) Coal and Coalbed Gas, Fueling the Future. Elsevier Science, Waltham.

[36] Ross, P. (1994) The Scotts Run Coalfield from the Great War to the Great Depression: A Study in Overdevelopment. West Virginia Archives and History, 53, 21-42. http://www.wvculture.org/History/journal_wvh/wvh53-3.html

[37] Maloney, J.C. (2011) Back to the Land: Arthurdale, FDR's New Deal, and the Costs of Economic Planning. John Wiley \& Sons, Inc., Hoboken.

[38] Sofya, B.L. (2008) The Great Depression of 1929 in the United States of America: Causes, Effects and Recovery. Ph.D. Thesis, University of Oran, Es Senia. http://www.univ-oran1.dz/theses/document/TH3641.pdf

[39] Doepke, M., Hazan, M. and Maoz, Y. (2015) The Baby Boom and World War II: A Macroeconomic Analysis. Review of Economic Studies, 82, 1031-1073. http://www.nber.org/papers/w13707.pdf

[40] Potter, S. (2013) Family Ideals: The Diverse Meanings of Residential Space in Chicago during the Post-World War II Baby Boom. Journal of Urban History, 39, 59-78. http://dx.doi.org/10.1177/0096144212463545

[41] Harris, A.R. and Tichenor, J.D. (2010) A History of the U.S. Political System: Ideas, Interests, and Institutions. Vol. 3, ABC-CLIO, Santa Barbara.

[42] Bussière, B. (2007) Colloquium 2004: Hydro-Geotechnical Properties of Hard Rock Tailings from Metal Mines and Emerging Geo-Environmental Disposal Approaches. Canadian Geotechnical Journal, 44, 1019-1052. http://dx.doi.org/10.1139/T07-040

[43] Reinhardt, C.H. (1999) Acid Mine Drainage in Pennsylvania Streams: "Ironing out” the Problem. Department of Horticultural Science, University of Minnesota, Minneapolis. Retrieved from the University of Minnesota Digital Conservancy. http://hdl.handle.net/11299/59448

[44] Demchak, J., Skousen, J. and McDonald, L.M. (2004) Longevity of Acid Discharges from Underground Mines Located above Regional Water Table. Journal of Environmental Quality, 33, 656-668. http://dx.doi.org/10.2134/jeq2004.6560

[45] Tuchman, R.J. and Brinkley, R.F. (1990) A History of the Bureau of Mines Pittsburgh Research Center. US Bureau of Mines. https://stacks.cdc.gov/view/cdc/9743

[46] Brant, R.A. and Moulton, E.Q. (1960) MD60-7 Acid Mine Drainage Manual. Ohio State University Engineering Experiment Station, Bulletins, 179, 40.

[47] Smith, V.J. (1999) Colloquium on Geology, Mineralogy, and Human Welfare. National Academy of Sciences, Washington DC.

[48] Herlihy, A.T., Kaufman, P.R., Mitch, M.E. and Brown, D.D. (1990) Regional Estimates of Acid Mine Drainage Impact on Streams in the Mid-Atlantic and Southeastern United States. Water, Air and Soil Pollution, 50, 91-107. http://dx.doi.org/10.1007/bf00284786

[49] Copeland, C. (2014) Clean Water Act: A Summary of the Law. Congressional Research Service. https://www.fas.org/sgp/crs/misc/RL30030.pdf

[50] Huntsman, B.E., Solch, J.B. and Porter, M.D. (1978) Utilization of a Sphagnum Species Dominated Bog for Coal Acid Mine Drainage Abatement. Abstracts of the 91st Annual Meeting Geologic Society America, Toronto, 23-26 October 1978, 322. 
[51] Chotpantarat, S. (2011) A Review of Static Tests and Recent Studies. American Journal of Applied Sciences, 8, 400406. http://thescipub.com/PDF/ajassp.2011.400.406.pdf http://dx.doi.org/10.3844/ajassp.2011.400.406

[52] Krishnan, N. (2008) Get Real Money for College: A Financial Handbook of Scholarship Opportunities and Education Loan Options for Students from Middle School through Graduate School. Author House, Bloomington.

[53] US Environmental Protection Agency (1995) Streams with Fisheries Impacted by Acid Mine Drainage in MD, OH, PA, VA, and WV. USEPA, Philadelphia.

[54] International Energy Agency (IEA) (2015) Coal Information 2015. IEA. http://www.oecd-ilibrary.org/energy/coal-information-2015_coal-2015-en

[55] Swart, E. (2009) The South African Legislative Framework for Mine Closure. The Journal of the South African Institute of Mining and Metallurgy, 10, 489-492. http://www.saimm.co.za/Journal/v103n08p489.pdf

[56] Simon, P. (2009) Jan van Riebeeck as Pioneering Explorer and Conservator of Natural Resources at the Cape of Good Hope (1652-62). Environment and History, 15, 3-33. http://dx.doi.org/10.3197/096734009X404644

[57] Watson, L.R. (2012) Slave Emancipation and Racial Attitudes in Nineteenth-Century South Africa. Cambridge University Press, Cambridge. http://dx.doi.org/10.1017/CBO9781139135146

[58] Harington, J.S., McGlashan, N.D. and Chelkowska, E.Z. (2004) A Century of Migrant Labour in the Gold Mines of South Africa. The Journal of the South African Institute of Mining and Metallurgy, 104, 65-72. http://www.saimm.co.za/Journal/v104n02p065.pdf

[59] Talbot, A.F. (1913) Railway Wonders of the World. Cassell and Company Ltd., London, 606. http://www.archive.org/stream/railwaywondersof00talb4\#page/n7/mode/1up

[60] Forney, M.N. (1893) South African Railroads. The Railroad and Engineering Journal, 67, 570-571. https://archive.org/details/americanengineer66newy

[61] Hopkins, P. (2006) Ghosts of South Africa. Zebra Press, Reproduced by Hirt \& Carter, Cape.

[62] Kuitenbrouwer, V.J.J. (2010) Dutch Pro-Boer Propaganda and the South African War (1899-1902). Ph.D. Thesis, University of Amsterdam, Amsterdam. http://dare.uva.nl/document/2/72545

[63] Penrose, R.A.F. (1907) The Witwatersrand Gold Region, Transvaal, South Africa as Seen in Recent Mining Developments. The Journal of Geology, 15, 735-749. http://dx.doi.org/10.1086/621471

[64] Jeffrey, L.S. (2005) Characterization of the Coal Resources of South Africa. The Journal of The South African Institute of Mining and Metallurgy, 105, 95-102. http://www.saimm.co.za/Journal/v105n02p095.pdf

[65] Christopher, J.A. (2001) The Atlas of Changing South Africa. 2nd Edition, Routledge, London.

[66] Frank, N.M.B. (2013) Exploring the Linkages between Land Management Institutions, Land Degradation and Acid Mine Drainage: The Case of the West Rand Goldfield. http://wiredspace.wits.ac.za/handle/10539/12873

[67] Costello, C. (2003) Acid Mine Drainage: Innovative Treatment Technologies. US Environmental Protection Agency. http://www.brownfieldstsc.org/pdfs/amdinnovativetrttech_03.pdf

[68] Council for Geoscience (2010) Mine Water Management in the Witwatersrand Gold Fields with Special Emphasis on Acid Mine Drainage: Report to the Inter-Ministerial Committee on Acid Mine Drainage. https://www.dwa.gov.za/Documents/ACIDReport.pdf

[69] Shank, G. (1991) Introduction: South Africa in Transition. Social Justice, 18, 1-2.

[70] Dersso, A.S. (2012) The Quest for Pax Africana: The Case of the African Union’s Peace and Security Regime. African Journal on Conflict Resolution, 12, 11-47. file:///C:/Users/sinzi/Downloads/ch_1.pdf

[71] Karim, A.Q. and Karim, A.S. (2002) The Evolving HIV Epidemic in South Africa. International Journal of Epidemiology, 31, 37-40. http://ije.oxfordjournals.org/content/31/1/37.full.pdf+html http://dx.doi.org/10.1093/ije/31.1.37

[72] Van Eeden, E.S., Liefferink, M. and Durand, J.F. (2009) Legal Issues Concerning Mine Closure and Social Responsibility on the West Rand. Journal for Transdisciplinary Research in Southern Africa, 5, 51-71. http://cer.org.za/wp-content/uploads/2010/05/Van-Eeden-Liefferink-and-Durand-2009-AMD-and-Wonderfonteinspruit .pdf

[73] Fourie, M. (2014) Tales from the Trenches: The Unfulfilled Promise of the Constitutional Environmental Right in South Africa. New York Law School Workshop on Constitutional Rights, Judicial Independence and the Transition to Democracy: Twenty Years of South African Constitutionalism, New York, 13-16 November 2014, 1-39. http://www.nylslawreview.com/wp-content/uploads/sites/16/2014/10/Fourie.pdf

[74] Banerjee, A., Galiani, S., Levinsohn, J., McLaren, Z. and Woolard, I. (2008) Why Has Unemployment Risen in the New South Africa? Economics of Transition, 16, 715-740. http://economics.mit.edu/files/2883 
[75] Munnik, V. (2010) The Social and Environmental Consequences of Coal Mining in South Africa: A Case Study. http://www.bothends.org/uploaded_files/uploadlibraryitem/1case_study_South_Africa_updated.pdf

[76] Ferreira, I.W. and Lloyd, H.R. (2002) Developmental Issues and Environmental Policy in South Africa. Africa Insight, 32, 20-24. http://www.eolss.net/sample-chapters/c14/e1-34-06-03.pdf http://dx.doi.org/10.4314/ai.v32i1.22294

[77] Brady, B.C.K., Smith, W.M. and Schueck, J. (1998) Coal Mine Drainage Prediction and Pollution Prevention in Pennsylvania. The Pennsylvania Department of Environmental Protection, Pennsylvania. http://www.osmre.gov/resources/library/pub/cmdppp.pdf

[78] Geneslaw, H. (1994) Cleanup of National Priorities List Sites, Functional Equivalence, and the NEPA Environmental Impact Statement. Journal of Land Use and Environmental Law, 10, 127-153. http://archive.law.fsu.edu/journals/landuse/Vol101/geneslaw.pdf

[79] Shields, J.D., Solar, V.S. and Langer, H.W. (2006) Sustainable Development and Industrial Minerals. In: Kogel, E.J., Trivedi, C.N., Barker, M.J. and Krukowski, T.S., Eds., Industrial Minerals and Rocks: Commodities, Markets, and Uses, 7th Edition, Society for Mining, Metallurgy, and Exploration, Inc., Colorado, 133-142.

[80] Mhlongo, E.S. and Amponsah-Dacosta, F. (2016) A Review of Problems and Solutions of Abandoned Mines in South Africa. International Journal of Mining, Reclamation and Environment, 30, 279-294. http://www.tandfonline.com/doi/pdf/10.1080/17480930.2015.1044046 http://dx.doi.org/10.1080/17480930.2015.1044046

[81] Bezuidenhout, N., Verburg, R., Chatwin, T. and Ferguson, K. (2009) INAP’s Global Acid Rock Drainage Guide and the Current State of Acid Rock Drainage Assessment \& Management in South Africa. Proceedings of the International Mine Water Conference, Pretoria, 19-23 October 2009, 29-37.

[82] Nahman, A., Wise, R. and De Lange, W. (2009) Environmental and Resource Economics in South Africa: Status Quo and Lessons for Developing Countries. South African Journal of Science, 105, 350-355. http://www.scielo.org.za/pdf/sajs/v105n9-10/a1110510.pdf

\section{Submit or recommend next manuscript to SCIRP and we will provide best service for you:}

Accepting pre-submission inquiries through Email, Facebook, LinkedIn, Twitter, etc. A wide selection of journals (inclusive of 9 subjects, more than 200 journals)

Providing 24-hour high-quality service

User-friendly online submission system

Fair and swift peer-review system

Efficient typesetting and proofreading procedure

Display of the result of downloads and visits, as well as the number of cited articles

Maximum dissemination of your research work

Submit your manuscript at: http://papersubmission.scirp.org/ 